\title{
PENGARUH KOMPENSASI DAN BEBAN KERJA TERHADAP KINERJA MELALUI KEPUASAN KERJA PEGAWAI UKPBJ SEKRETARIAT DAERAH MOJOKERTO
}

\author{
Anny Sugiarti, Ernani Hadiyati, Dwi Orbaningsih. \\ Program Pasca Sarjana Magister Manajemen Universitas Gajayana Malang \\ e-mail: annysugiarti@gmail.com
}

\begin{abstract}
This study used the quantitative data with an explanatory research method, while the samples were 44 employees with the status of the Civil Apparatus of Nation at the UKPBJ Regional Secretariat of Mojokerto City with details: 7 employees of the Election Working Group, 29 Procurement Officers, 8 employees of the Secretariat Section. Structural Equation Modeling (SEM) based on Partial Least Square (PLS) was chosen to analyze the hypothesis. The results of this study indicated that: "i) compensation didn't has a direct effect on employee job satisfaction at the UKPBJ Regional Secretariat of Mojokerto City"; ii) workload didn't has a direct effect on employee job satisfaction at the Regional Secretariat UKPBJ Mojokerto City; iii) compensation didn't has a direct effect on the performance of employees at the Regional Secretariat UKPBJ Mojokerto City; iv) workload has a direct influence on employee performance at the Regional Secretariat UKPBJ Mojokerto City; v) job satisfaction didn't have a direct effect on employee performance at the Regional Secretariat UKPBJ Mojokerto City; vi) compensation didn't have an indirect effect on employee performance through job satisfaction at the UKPBJ Regional Secretariat of Mojokerto City; vii) workload didn't have an indirect effect on employee performance through job satisfaction at the UKPBJ Regional Secretariat of Mojokerto City.
\end{abstract}

Keywords: compensation; workload; job satisfaction; employee's performance

\begin{abstract}
ABSTRAK
Penelitian ini menggunakan quantitative data dengan metode explanatory research, sedangkan sampel yang digunakan yakni sebanyak 44 orang berstatus Aparatur Sipil Nergara (ASN) di UKPBJ Sekertariat Daerah Kota Mojokerto dengan rincian: 7 orang pegawai Pokja Pemilihan, 29 orang Pejabat Pengadaan, 8 orang pegawai Bagian Sekretariat. Structural Equation Modelling (SEM) berbasis Partial Least Square (PLS) dipilih dalam menganalisis hipotesa. Hasil penelitian ini menunjukkan bahwa: "i) kompensasi tidak memiliki pengaruh langsung terhadap kepuasan kerja pegawai di UKPBJ Sekertariat Daerah Kota Mojokerto"; ii) beban kerja tidak memiliki pengaruh langsung terhadap kepuasan kerja pegawai di UKPBJ Sekertariat Daerah Kota Mojokerto; iii) kompensasi tidak memiliki pengaruh langsung terhadap kinerja pegawai di UKPBJ Sekertariat Daerah Kota Mojokerto; iv) beban kerja memiliki pengaruh langsung terhadap kinerja pegawai di UKPBJ Sekertariat Daerah Kota Mojokerto; v) kepuasan kerja tidak memiliki pengaruh langsung terhadap kinerja pegawai di UKPBJ Sekertariat Daerah Kota Mojokerto; vi) kompensasi tidak memiliki pengaruh tidak langsung terhadap kinerja pegawai melalui kepuasan kerja di UKPBJ Sekertariat Daerah Kota Mojokerto; vii) beban kerja tidak memiliki pengaruh tidak langsung terhadap kinerja pegawai melalui kepuasan kerja di UKPBJ Sekertariat Daerah Kota Mojokerto.
\end{abstract}

Kata kunci: kompensasi; beban kerja; kepuasan kerja; kinerja pegawai

\section{PENDAHULUAN}

Organisasi dalam pencapaian target/tujuannya perlu didukung manusia yang berkualitas. Salah satu organisasi yaitu "Lembaga Kebijakan Pengadaan Barang/Jasa Pemerintah (LKPP)" memiliki kebijakan baru sebagai salah satu tujuannya dengan membentuk "Unit Kerja
Pengadaan Barang/Jasa (UKPBJ)" yang fokus pada aktivitas pengadaan yang bertujuan melakukan aktivitas pengarahan kerja, pengelolaan information system, serta e-katalog yang berkapabilitas sehingga pembelanjaan pemerintahan menjadi tepat sasaran, efisien, dan telah sesui dengan rencana anggaran yang dapat 
didukung oleh manusia berkualitas sesuai faktorfaktor pendukung seperti: "kompensasi, beban kerja, kepuasan kerja, dan kinerja pegawai" sebagai ikatan kerja sama, motivasi, serta stabilitas pada kepegawaian.

Pemberian kompensasi dan beban kerja dapat dikatakan efektif, karena organisasi mampu memonitor kinerja pegawai secara maksimal, dimana pada Aparatur Sipil Negara (ASN) telah berdasarkan Peraturan Walikota Mojokerto Nomor 21/2020 sebagai kriteria pemberian TPP (Tambahan Penghasilan Pegawai) atau yang dikenal dengan kompensasi, yang kemudian disesuaikan dengan beban kerja pegawai sehingga akan menghasilkan kepuasan dan kinerja pegawai menjadi lebih baik. Ketidakpuasan pegawai dalam pemberian kompensasi dan beban pada pekerjaan, maka akan menjadi titik awal munculnya berbagai macam permasalahan di dalam organisasi seperti peningkatan intensitas ketidakhadiran, konflik antar pekerja maupun dengan level manajemen, pemogokan kerja, menurunnya moril dan motivasi kerja atau siklus pegawai yang pendek dan cepat. Tetapi sebaliknya jika pemberian kompensasi dan beban kerja kepada pegawai tepat, maka menghasilkan dampak positif pada pegawai seperti kepuasan kerja yang lebih, serta tingginya tingkat kinerja pegawai (Paramitadewi, 2017).

Berdasarkan penjelasan tentang kompensasi, beban kerja, kepuasan kerja, dan kinerja UKPBJ Sekertariat Daerah Kota Mojokerto, membentuk rumusan masalah:

1. Apakah secara langsung kompensasi berpengaruh terhadap kepuasan kerja pegawai di UKPBJ Sekertariat Daerah Mojokerto?

2. Apakah secara langsung beban kerja berpengaruh terhadap kepuasan kerja pegawai di UKPBJ Sekertariat Daerah Mojokerto?

3. Apakah secara langsung kompensasi berpengaruh terhadap kinerja pegawai di UKPBJ Sekertariat Daerah Mojokerto?

4. Apakah secara langsung beban kerja berpengaruh terhadap kinerja pegawai di UKPBJ Sekertariat Daerah Mojokerto?

5. Apakah secara langsung kepuasan kerja berpengaruh terhadap kinerja pegawai di UKPBJ Sekertariat Daerah Mojokerto?

6. Apakah secara tidak langsung kompensasi berpengaruh terhadap kinerja melalui kepuasan kerja pegawai di UKPBJ Sekertariat Daerah Mojokerto?

7. Apakah secara tidak langsung beban kerja berpengaruh terhadap kinerja melalui kepuasan
Pengaruh Kompensasi dan Beban Kerja... (Anny Sugiarti, Ernani Hadiyati, Dwi Orbaningsih)

kerja pegawai di UKPBJ Sekertariat Daerah Mojokerto?

Sedangkan tujuan penelitian yang dilakukan:

1. Untuk menganalisis pengaruh langsung kompensasi terhadap kepuasan kerja pegawai di UKPBJ Sekertariat Daerah Mojokerto.

2. Untuk menganalisis pengaruh langsung beban kerja terhadap kepuasan kerja pegawai di UKPBJ Sekertariat Daerah Mojokerto.

3. Untuk menganalisis pengaruh langsung kompensasi terhadap kinerja pegawai di UKPBJ Sekertariat Daerah Mojokerto.

4. Untuk menganalisis pengaruh langsung beban kerja terhadap kinerja pegawai di UKPBJ Sekertariat Daerah Mojokerto.

5. Untuk menganalisis pengaruh langsung kepuasan kerja terhadap kinerja pegawai di UKPBJ Sekertariat Daerah Mojokerto.

6. Untuk menganalisis pengaruh tidak langsung kompensasi terhadap kinerja melalui kepuasan kerja pegawai di UKPBJ Sekertariat Daerah Mojokerto.

7. Untuk menganalisis pengaruh tidak langsung beban kerja terhadap kinerja melalui kepuasan kerja pegawai di UKPBJ Sekertariat Daerah Mojokerto.

\section{Tinjauan Literatur}

Mangkunegara dalam Handayani dan Soliha (2020) menjelaskan kinerja karyawan sebagai pencapaian karyawan atau prestasi yang telah dilakukan karyawan atas pekerjaan berkualitas dan berkuantitas yang telah dilakukannya sesuai dengan tanggung jawab masing-masing. Kinerja yang baik, tentunya tidak mungkin terjadi secara sendirinya, melainkan membutuhkan beberapa faktor pendukung diantaranya kompensasi, beban kerja, serta kepuasan kerja.

Faktor pendukung peningkatan kinerja pegawai yang pertama adalah pemberian kompensasi karena dianggap vital dalam penerapan sistem Manajemen Sumber Daya Manusia (MSDM). Wilson (2012) di dalam penelitiannya menjelaskan bahwa kompensasi seringnya diterima dalam bentuk keuangan yang dibayarkan secara langsung seperti gaji pokok, upah, insentif atau bonus. Jika pegawai menganggap kompensasi mereka tidak memadai, motivasi, kepuasan kerja, dan semangat serta kinerja karyawan pun akan menurun. Apabila sistem pemberian kompensasi tidak dianggarkan secara tepat, maka konsekuensinya perusahaan 
akan kehilangan pegawai yang berpotensi dan terpaksa menganggarkan biaya lebih untuk recruitment dan pelatihan. Pemberian kompensasi yang tinggi pada pegawai akan menghasilkan peningkatan kinerja.

Faktor pendukung selanjutnya dalam peningkatan kinerja pegawai adalah beban kerja. Pada "Beban kerja menjadi target kerja secara personal maupun kelompok melalui programprogram unit kerja yang harus dicapai dalam periode tertentu (Kep. Men. PAN Nomor: KEP/75/.PAN/7/2004)". Sedangkan Haryono (2004) di dalam penelitiannya menjelaskan beban kerja merupakan sejumlah tanggung jawab baik secara berlebihan maupun dalam batas normal yang harus mampu diselesaikan secara personal atau berkelompok dalam batas waktu tertentu. Beban kerja perlu diterapkan melalui programprogram unit kerja unit kerja yang selanjutnya dijabarkan menjadi target pekerjaan untuk setiap jabatan. Target dalam pekerjaan inilah yang sering menjadi beban kerja bagi pegawai dan memicu penurunan kinerja.

Kemudian faktor yang terakhir sebagai pendukung kinerja pegawai yakni kepuasan kerja. Priansa (2014:291) menjelaskan kepuasan kerja adalah sikap secara emosional berupa perasaan bahagia, nyaman, tenang, menyenangkan dan mencintai pekerjaan yang dilakukan, tercermin dari sikap moral, disiplin, dan prestasi kerja pegawai. Kepuasan kerja menggambarkan perasaan positif pegawai terhadap pekerjaan dan lingkungan kerjanya sehingga mampu menghasilkan karyawan yang produktif. Ketika pegawai merasakan kepuasan dalam bekerja, maka sikap emosional yang positif akan tersalurkan ke dalam pekerjaannya sehingga kinerja pun menjadi meningkat.

\section{METODE PENELITIAN}

\section{Jenis Data dan Sumber Data}

Penelitian ini memilih jenis data kuantitatif yang terkandung dalam kuesioner dan selanjutnya diterjemahkan ke dalam angka yang kemudian akan diolah menggunakan perhitungan statistik dan selanjutnya akan dianalisis. Sumber data data primer terpilih dalam penelitian ini yang diperoleh langsung dari sumbernya, berupa jawaban responden berkaitan dengan variabel penelitian yaitu kompensasi, beban kerja, kinerja dan kepuasan kerja.

\section{Populasi dan Sampel}

Populasi dari penelitian ini adalah 46 pegawai berstatus ASN pada UKPBJ Sekretariat Daerah Kota Mojokerto, sedangkan dalam pengambilan sampel dipergunakan teknik Purposive Sampling dengan karakteristik pegawai yang berstatus Aparatur Sipil Negara (ASN) dan diperoleh sebanyak 44 orang pegawai sebagai sampel dengan rincian jabatan: pegawai Pokja Pemilihan sebanyak 7 orang, Pejabat Pengadaan sebanyak 29 orang, selebihnya adalah pegawai yang bertugas di bagian sekretariat sebanyak 8 orang.

\section{Teknik Analisa Data}

"Structural Equation Modelling (SEM) berbasis Partial Least Square (PLS) dengan aplikasi SmartPLS" terpilih menjadi teknik analisis dalam penelitian ini, dimana menurut Sholihin \& Ratmono (2013) adalah penggabungan pendekatan analisis faktor, model struktural dan analisis jalur melalui proses pengolahan dan analisis data statistik yang merupakan perkembangan analisis jalur (Path Analysis), dengan dua model analisa data, yaitu: "Outer Model (Convergent Validity, Descriminant Validity, dan Composite Reliability) serta Inner Model ( $R$-squared $R^{2}$ dan Predictive Relevance $\left.Q^{2}\right)^{\prime \prime}$.

\section{PEMBAHASAN}

\section{Model Struktural dalam Outer Model}

Sebelum melakukan pengujian model struktural Outer Model, maka terlebih dahulu perlu dijabarkannya definisi operasional pada variabel-variabel berikut:

1. Kompensasi $\left(\mathrm{X}_{1}\right)$

Kompensasi adalah segala sesuatu berupa uang yang diberikan oleh Pemerintah Kota Mojokerto kepada pegawai sebagai konsekuensi menjadi pengelola pengadaan barang dan jasa. Adapun indikator kompensasi adalah sebagai berikut (Katidjan, Pawirosumarto, dan Isnaryadi, 2017):

a. Upah

Gaji yang diberikan sesuai ketentuan jabatan.

b. Insentif

Tambahan penghasilan sesuai beban kerja.

c. Tunjangan

Tunjangan kinerja sesuai yang dijanjikan.

2. Beban Kerja $\left(X_{2}\right)$

Beban kerja adalah suatu kondisi dari pekerjaan dengan uraian tugasnya yang harus diselesaikan pada batas waktu tertentu. Adapun 
Pengaruh Kompensasi dan Beban Kerja... (Anny Sugiarti, Ernani Hadiyati, Dwi Orbaningsih) indikator beban kerja adalah sebagai berikut (Putra, 2017):

a. Target yang harus dicapai Capaian kinerja sesuai job

b. Kondisi pekerjaannya Beban kerja sesuai jabatan

c. Skala pekerjaan Pekerjaan yang dilakukan sesuai standar kerja

3. Kinerja Karyawan (Y)

Kinerja merupakan suatu hasil kerja yang telah dicapai yang sesuai dengan tugas dan tanggung jawab yang telah diberikan. Adapun indikator kinerja karyawan adalah sebagai berikut (Robbins dalam Ghozali, 2017):

a. Kualitas

Karyawan dapat menyelesaikan pekerjaan dengan teliti.

b. Kuantitas

Karyawan dapat menyelesaikan banyak pekerjaan dalam satu waktu.

c. Ketepatan Waktu

Karyawan menyelesaikan pekerjaan tepat waktu.

d. Efektivitas

Karyawan menyelesaikan pekerjaan dengan efektif.

e. Kemandirian

Karyawan mampu menyelesaikan pekerjaan secara mandiri.

f. Kemampuan bekerja sama

Karyawan mampu bekerjasama dalam tim kerja.

4. Kepuasan Kerja ( $Z$ )

Kepuasan kerja adalah sikap emosional yang menyenangkan dan mencintai pekerjaanya. Sikap ini dicerminkan oleh moral kerja, kedisiplinan, dan prestasi kerja. Adapun indikator kepuasan kerja (Hasibuan dalam Habe, 2012):

a. Balas jasa yang adil

Karyawan merasa puas menerima tunjangan yang layak

b. Penempatan yang tepat sesuai dengan keahlian

Beban kerja karyawan sesuai job description dan keahliannya.

c. Berat ringannya pekerjaan

Beban kerja karyawan disesuaikan dengan jabatan.

Setelah indikator-indikator tersebut diujikan kepada beberapa karyawan dan diolah menggunakan SmartPLS 3.0 maka diperoleh model struktural Outer Model dengan menggunakan tiga teknik analisa data, yaitu "Convergent Validity, Descriminant Validity, dan Composite Reliability".

itentukan

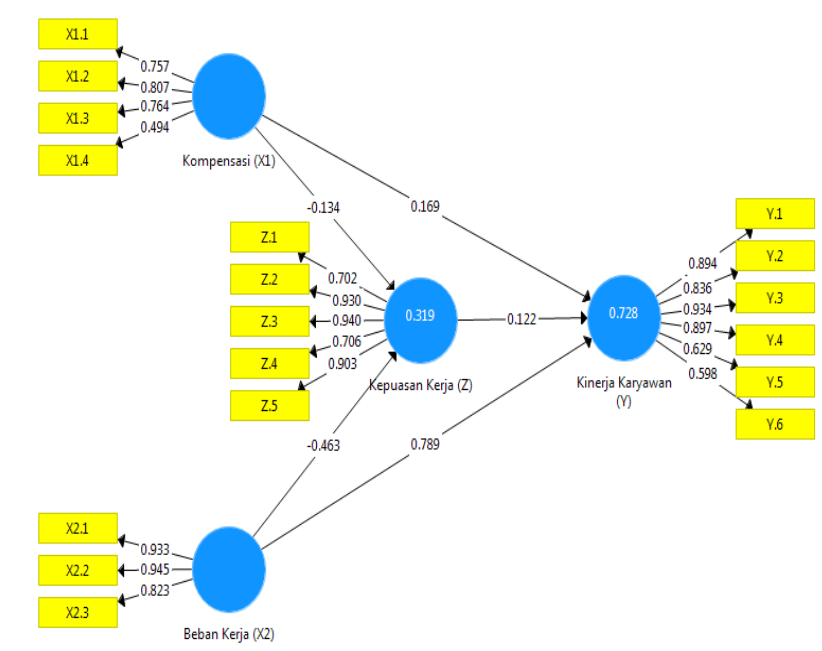

Model Struktural pada Outer Model

Tabel 1

Outer Loadings (Loading Factor)

\begin{tabular}{|c|c|c|c|c|}
\hline & X1 & $\mathrm{X} 2$ & $\mathbf{Y}$ & $\mathbf{Z}$ \\
\hline X1.1 & 0,757 & & & \\
\hline $\mathrm{X} 1.2$ & 0,807 & & & \\
\hline $\mathrm{X} 1.3$ & 0,764 & & & \\
\hline X1.4 & 0,494 & & & \\
\hline $\mathrm{X} 2.1$ & & 0,933 & & \\
\hline $\mathrm{X} 2.2$ & & 0,945 & & \\
\hline $\mathrm{X} 2.3$ & & 0,823 & & \\
\hline Y.1 & & & 0,894 & \\
\hline Y.2 & & & 0,836 & \\
\hline Y.3 & & & 0,934 & \\
\hline Y.4 & & & 0,897 & \\
\hline Y.5 & & & 0,629 & \\
\hline Y.6 & & & 0,598 & \\
\hline Z.1 & & & & 0,702 \\
\hline Z.2 & & & & 0,930 \\
\hline Z.3 & & & & 0,940 \\
\hline Z.4 & & & & 0,706 \\
\hline Z.5 & & & & 0,903 \\
\hline
\end{tabular}

Sumber: Data diolah SmartPLS, 2020

\section{Convergent Validity}

Model pengukuran dengan menilai korelasi antara item score melalui pengembangan skala pengukuran dengan menggunakan Loading Factor, yaitu nilai konstruk pada nilai komponen 
yang saling berkorelasi dan memiliki syarat $>0,4$ agar butir-butir pertanyaan dalam kuesioner penelitian dikatakan valid atau sah (Prayatna dan Jawas, 2012). Setelah dilakukan pengujian, diperoleh hasil pada Loading Factor seluruhnya telah memenuhi syarat > 0,4sehingga seluruh butir-butir pertanyaan dalam kuesioner penelitian dikatakan valid atau sah, yang terlihat pada Tabel1

\section{Descriminant Validity}

Digunakan untuk membandingkan antara nilai "Square Root of Avarage Variance Extracted (AVE)" dengan melalui Fornell-Larcker yang dikatakan baik jika nilai kuadrat AVE pada masing-masing konstruk eksogen (nilai pada diagonal) melebihi nilai kontruk yang terdapat dibawah diagonal (Ghozali, 2017 dalam Asbari, Santoso, dan Purwanto, 2019). Tabel 2 tersusun nilai Fornell-Larcker yang telah memenuhi Descriminant Validity.

Tabel 2

Descriminant Validity (Fornell-Larcker)

\begin{tabular}{ccccc}
\hline & $\mathrm{X} 1$ & $\mathrm{X} 2$ & $\mathrm{Y}$ & $\mathrm{Z}$ \\
\hline $\mathrm{X} 1$ & $\mathbf{0 , 7 6 1}$ & 0,702 & 0,668 & $-0,459$ \\
\hline $\mathrm{X} 2$ & & $\mathbf{0 , 9 0 2}$ & & \\
\hline $\mathrm{Y}$ & & $-0,557$ & $\mathbf{0 , 8 0 9}$ & $-0,395$ \\
\hline $\mathrm{Z}$ & & 0,702 & & $\mathbf{0 , 8 4 3}$ \\
\hline
\end{tabular}

Sumber: Data diolah SmartPLS, 2020

3. Composite Reliability, Average Variance Extracted (AVE) dan Cronbach Alpha

Digunakan untuk melihat kemampuan pada instrumen telah stabil dan konsisten dalam pengukuran konsepnya dengan syarat "Composite Reliability dan Cronbach's Alpha $\geq 0,6$ serta nilai Average Variance Extracted (AVE) $\geq 0,5 "$ agar dapat dikatakan seluruh butir-butir pertanyaan dalam kuesioner penelitian reliabel atau layak (Ghozali, 2017 dalam Tjio dan Anggela, 2017). Tabel 3 memperlihatkan seluruh butir-butir pertanyaan dalam kuesioner penelitian dikatakan reliabel atau layak:

Tabel 3

Composite Reliability, Average Variance Extracted (AVE) dan Cronbach Alpha

\begin{tabular}{cccc}
\hline $\begin{array}{c}\text { Cronbach's } \\
\text { Alpha }\end{array}$ & $\begin{array}{c}\text { Composite } \\
\text { Reliability }\end{array}$ & $\begin{array}{c}\text { Average } \\
\text { Variance } \\
\text { Extracted } \\
\text { (AVE) }\end{array}$ \\
\hline $\mathrm{X} 1$ & 0,690 & 0,803 & 0,513 \\
\hline $\mathrm{X} 2$ & 0,883 & 0,920 & 0,814 \\
\hline
\end{tabular}

\begin{tabular}{cccc}
\hline $\mathrm{Y}$ & 0,888 & 0,917 & 0,654 \\
\hline $\mathrm{Z}$ & 0,906 & 0,924 & 0,711 \\
\hline
\end{tabular}

Sumber: Data diolah SmartPLS, 2020

\section{Model Struktural dalam Inner Model}

Pengujian ini menggunakan $R$-squared $\left(R^{2}\right)$ dan Predictive Relevance $\left(Q^{2}\right)$ sebagai model struktural dalam Inner Model untuk melihat hubungan antar nilai konstruk yang selanjutnya dievaluasi untuk konstruk dependen dalam uji $\mathrm{t}$ dan analisa jalur.

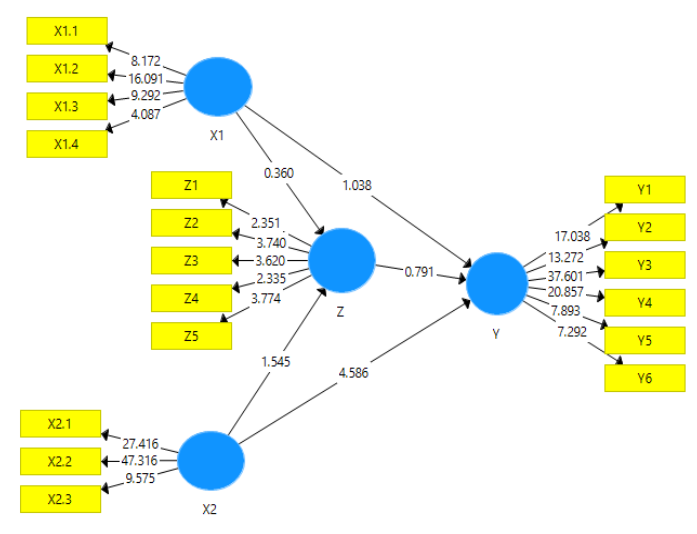

\section{Gambar 2}

\section{Model Struktural pada Inner Model}

\section{1. $R$-square (R2)}

Pengujian $R$-square yang merupakan uji Goodness-Fit Model dengan melihat nilai $R$ square pada model. Terlihat pada Tabel 4 diperoleh nilai R-square 0,319 atau 31,9 persen pada Kepuasan Kerja (Z) dapat dipengaruhi Kompensasi (X1) dan Beban Kerja (X2), kemudian sisanya 68,1 persen dipengaruhi oleh konstruk lain yang tidak tercatat dalam penelitian ini. Selanjutnya nilai $R$-square 0,728 atau 72,8 persen pada Kinerja Karyawan (Y) dapat dipengaruhi oleh Kompensasi (X1) dan Beban Kerja (X2), sedangkan sisanya sebesar 27,2 persen dipengaruhi oleh konstruk lain yang tidak tercatat dalam penelitian ini.

Tabel 4

R-Square $\left(\mathbf{R}^{2}\right)$

\begin{tabular}{cc}
\hline \multicolumn{2}{c}{$\boldsymbol{R}$-Square $\left(\mathbf{R}^{2}\right)$} \\
\hline $\mathrm{R}$-Square $\left(\mathrm{R}^{2}\right)$ \\
\hline $\mathrm{Z}$ & 0,319 \\
\hline
\end{tabular}

Sumber: Data diolah SmartPLS, 2020

2. Predictive Relevance $\left(Q^{2}\right)$

Predictive Relevance $\left(Q^{2}\right)$ untuk mengukur kemampuan model dalam memprediksi maupun 
p-ISSN 1693-1378

e-ISSN 2598-9952

memberikan informasi yang terkandung pada data. Pada dasarnya Predictive Relevance $\left(Q^{2}\right)$ sama fungsinya koefisien determinasi $\left(\mathrm{R}^{2}\right)$, tetapi dalam Predictive Relevance $\left(Q^{2}\right)$ memiliki syarat jika Predictive Relevance $\left(Q^{2}\right)>0$ maka kemampuan model dalam memprediksi maupun memberikan informasi yang terkandung pada data adalah relevan, tetapi jika Predictive Relevance $\left(Q^{2}\right)<0$ maka kemampuan model dalam memprediksi maupun memberikan informasi yang terkandung pada data adalah kurang relevan (Halimah, 2017). Tabel $4 R$-square juga dapat menghitung nilai Predictive Relevance $\left(Q^{2}\right)$ melalui formulasi:

Predictive Relevance $\left(Q^{2}\right)$

$=1-\left[\left(1-R^{2} z\right) \cdot\left(1-R^{2} y\right)\right]$

$=1-[(1-0,319) \cdot(1-0,728)]$

$=1-[(0,681) \cdot(0,272)]$

$=1-[0,185232]$

$=0,814768$ atau 0,82

Hasil Predictive Relevance $\left(Q^{2}\right) \quad 0,82>0$ yang menunjukkan bahwa kemampuan model dalam memprediksi maupun memberikan informasi yang terkandung pada Kepuasan Kerja dan Kinerja Pegawai adalah relevan serta memiliki model fit yang baik atau layak.

3. Uji Hipotesis pada "Structural Equation Modelling (SEM) berbasis Partial Least Square (PLS)"

Uji hipotesis melalui metode Bootstrapping untuk memperoleh informasi dalam menjelaskan hubungan antara variabel-variabel penelitian sehingga dapat meminimalisir masalah ketidaknormalan dalam penelitian, yang terlihat pada Tabel 5 dan 6:

\section{Tabel 5}

Path Coefficient

\begin{tabular}{ccccc}
\hline Hipotesa & $\begin{array}{c}\text { Hubungan } \\
\text { Variabel }\end{array}$ & $\begin{array}{c}\text { Original } \\
\text { Sample } \\
(\mathrm{O})\end{array}$ & $\begin{array}{c}\text { T Statistics } \\
(\mid \mathrm{O} / \text { STERR } \mid)\end{array}$ & P-value \\
\hline $\begin{array}{c}\text { Hipotesis } \\
1\end{array}$ & $\mathrm{X} 1$-> Z & $-0,134$ & 0,360 & 0,719 \\
\hline $\begin{array}{c}\text { Hipotesis } \\
2\end{array}$ & $\mathrm{X} 2->\mathrm{Z}$ & $-0,463$ & 1,545 & 0,123 \\
\hline $\begin{array}{c}\text { Hipotesis } \\
3\end{array}$ & $\mathrm{X} 1$-> Y & 0,169 & 1,038 & 0,300 \\
\hline $\begin{array}{c}\text { Hipotesis } \\
4\end{array}$ & $\mathrm{X} 2$-> Y & 0,789 & 4,586 & 0,000 \\
\hline $\begin{array}{c}\text { Hipotesis } \\
5\end{array}$ & $\mathrm{Z}$-> Y & 0,122 & 0,791 & 0,429 \\
\hline
\end{tabular}

Sumber: Data diolah SmartPLS, 2020
Pengaruh Kompensasi dan Beban Kerja... (Anny Sugiarti, Ernani Hadiyati, Dwi Orbaningsih)

Tabel 6

Specific Indirect Effect

\begin{tabular}{lccc}
\hline & $\begin{array}{c}\text { Koefisien } \\
\text { Tidak } \\
\text { langsung }\end{array}$ & $\begin{array}{c}\mathrm{T} \\
\text { Statistics }\end{array}$ & P-Values \\
\hline $\mathrm{X} 1$-> Z-> Y & $-0,016$ & 0,181 & 0,857 \\
\hline $\mathrm{X} 2$-> Z-> Y & $-0,056$ & 0,555 & 0,579 \\
\hline
\end{tabular}

Sumber: Data diolah SmartPLS, 2020

a. Hasil Path Coefficient pada Tabel 5 menunjukkan "t-statistic $(0,360)<\mathrm{t}$-tabel $(2,02108)$ dan $P$-value $(0,707)>\alpha=0,05$, sehingga dapat dikatakan Kompensasi tidak memiliki pengaruh secara langsung terhadap Kepuasan Kerja Pegawai dan memberikan kesimpulan bahwa hipotesis pertama ditolak". Hasil penelitian ini menujukkan bahwa ketika terdapat perubahan jumlah kompensasi pada pegawai UKPBJ Sekertariat Daerah Mojokerto, maka tidak akan mempengaruhi kepuasan kerja pegawainya. Sebab pembagian kompensasi kepada Aparatur Sipil Negara (ASN) telah disesuaikan dengan jabatan dan golongan masing-masing pegawai, sehingga kompensasi yang diterima oleh pegawai juga akan sama, tanpa memperhatikan porsi kerja masing-masing pegawai. Berdasarkan jawaban responden secara nyata telah membentuk hasil akhir bahwa tidak ada kaitan antara kompensasi yang diterima pegawai ASN dengan kepuasannya dalam melaksanakan tanggung jawab pekerjaan.

b. Hasil Path Coefficient pada Tabel 5 menunjukkan "t-statistic $(1,545)<\mathrm{t}$-tabel $(2,02108)$ dan $P$-value $(0,123)>\alpha=0,05$, sehingga dapat dikatakan Beban Kerja tidak memiliki pengaruh secara langsung terhadap Kepuasan Kerja Pegawai dan memberikan kesimpulan bahwa hipotesis kedua ditolak". Hasil penelitian ini menujukkan bahwa ketika terdapat penambahan beban pekerjaan pada pegawai UKPBJ Sekertariat Daerah Mojokerto, maka tidak akan mempengaruhi kepuasan kerja pegawainya. Sebab meskipun terdapat penambahan beban kerja, tidak akan berbeda dengan pekerjaan rutin masingmasing pegawai, hanya berbeda pada kuantitasnya saja bukan jenis pekerjaannya dan hal tersebut sangat jarang sekali terjadi, kecuali terdapat perubahan pimpinan yang membentuk kebijakan baru. Sehingga berdasarkan jawaban responden secara nyata telah membentuk hasil akhir bahwa tidak ada 
kaitan antara beban kerja yang diberikan kepada pegawai ASN dengan kepuasannya dalam melaksanakan tanggung jawab pekerjaan.

c. Hasil Path Coefficient pada Tabel 5 menunjukkan "t-statistic $(1,038)<\mathrm{t}$-tabel $(2,02108)$ dan $P$-value $(0,300)>\alpha=0,05$, sehingga dapat dikatakan Kompensasi tidak memiliki pengaruh secara langsung terhadap Kinerja Pegawai dan memberikan kesimpulan bahwa hipotesis ketiga ditolak". Hasil penelitian ini menujukkan bahwa ketika terdapat perubahan pada jumlah kompensasi pada pegawai UKPBJ Sekertariat Daerah Mojokerto, maka tidak akan mempengaruhi kinerja pegawainya. Sebab pembagian kompensasi kepada Aparatur Sipil Negara (ASN) telah disesuaikan dengan jabatan dan golongan masing-masing pegawai, sehingga kompensasi yang diterima oleh pegawai juga akan sama, tanpa memperhatikan porsi kerja masing-masing pegawai. Jika pada karyawan swasta, ketika kompensasi yang diberikan perusahaan kurang memadai, maka kinerja karyawan pun akan menurun, tetapi hal tersebut tidak berlaku pada pegawai pemerintahan sebab kompensasi yang diterima telah diatur negara dan bersifat sama pada masing-masing golongan dan jabatan ASN. Sehingga berdasarkan jawaban responden secara nyata telah membentuk hasil akhir bahwa tidak ada kaitan antara kompensasi yang diterima pegawai ASN dengan kinerjanya.

d. Hasil Path Coefficient pada Tabel 5 menunjukkan " $t$-statistic $(4,586)>\mathrm{t}$-tabel $(2,02108)$ dan $P$-value $(0,000)<\alpha=0,05$, sehingga dapat dikatakan Beban Kerja memiliki pengaruh secara langsung terhadap terhadap Kinerja Pegawai dan memberikan kesimpulan bahwa hipotesis keempat diterima". Hasil penelitian ini menujukkan bahwa ketika terdapat penambahan beban pekerjaan pada pegawai UKPBJ Sekertariat Daerah Mojokerto, maka akan mempengaruhi kinerja pegawainya. Sebab beban kerja yang bertambah dengan batas waktu penyelesaian yang singkat, maka pegawai dituntut untuk meningkatkan kinerjanya. Penambahan beban kerja ini seringkali terjadi ketika terdapat perubahan kebijakan Kepala UKPBJ Sekertariat Daerah Mojokerto, sehingga secara kesadaran diri masing-masing pegawai, kinerjanya menjadi lebih meningkat. Tetapi ketika tidak terjadi penambahan beban kerja, maka kinerja pegawai juga akan biasa-biasa saja. Berdasarkan jawaban responden secara nyata telah membentuk hasil akhir bahwa terdapat kaitan antara beban kerja yang diberikan kepada pegawai ASN dengan kinerjanya.

e. Hasil Path Coefficient pada Tabel 5 menunjukkan "t-statistic $(0,791)<\mathrm{t}$-tabel $(2,02108)$ dan $P$-value $(0,429)>\alpha=0,05$, sehingga dapat dikatakan Kepuasan Kerja tidak memiliki pengaruh secara langsung terhadap terhadap Kinerja Pegawai dan memberikan kesimpulan bahwa hipotesis kelima ditolak". Hasil penelitian ini menujukkan bahwa ketika kepuasan kerja pada pegawai UKPBJ Sekertariat Daerah Mojokerto meningkat maupun menurun, maka kinerja pegawai akan tetap sama. Posisi tanggung jawab sebagai pegawai Aparatur Sipil Negara (ASN), telah memiliki porsi pekerjaan masing-masing yang disesuai dengan dengan golongan dan level jabatannya. Rutinitas pekerjaan (kinerja) yang dilakukan pun akan sama dari waktu ke waktu, sehingga tingkat kepuasan kerja yang dirasakan pun akan sama. Oleh sebab itu, berdasarkan jawaban responden secara nyata telah membentuk hasil akhir bahwa tidak terdapat kaitan antara kepuasan kerja yang diraskan pegawai ASN dengan kinerjanya

f. Hasil Specific Indirect Effect pada Tabel 6 menunjukkan "t-statistic $(0,181)<\mathrm{t}$-tabel $(2,02108)$ dan $P$-value $(0,857)>\alpha=0,05$, sehingga dapat dikatakan Kompensasi tidak memiliki pengaruh secara tidak langsung terhadap Kinerja Pegawai melalui Kepuasan Kerja dan memberikan kesimpulan bahwa hipotesis keenam ditolak". Hasil penelitian ini menujukkan bahwa ketika terdapat perubahan pada jumlah kompensasi pegawai UKPBJ Sekertariat Daerah Mojokerto, maka tidak akan mempengaruhi kinerja pegawainya, sebab kepuasan kerja yang dirasakan pegawai juga sama (tidak meningkat/menurun). Ketika terjadi peningkatan pada kepuasan kerja pegawai meningkat, maka bukan dipengaruhi oleh kompenasi yang diterimanya, sebab kompenasai pegawai ASN diatur oleh negara. Selain itu pembagian kompensasi kepada Aparatur Sipil Negara (ASN) telah disesuaikan dengan jabatan dan golongan masing-masing pegawai, sehingga tidak akan 
mempengaruhi kepuasannya dalam bekerja, yang pada akhirnya juga tidak akan mempengaruhi perubahan kinerjanya. Berdasarkan jawaban responden, secara nyata telah membentuk hasil akhir bahwa tidak ada kaitan antara kompensasi yang diterima pegawai ASN dengan kepuasan kerja dan pada akhirnya juga tidak akan berdampak pada kinerjanya.

g. Hasil Specific Indirect Effect pada Tabel 6 menunjukkan " $t$-statistic $(0,555)<\mathrm{t}$-tabel $(2,02108)$ dan P-value $(0,579)>\alpha=0,05$, sehingga dapat dikatakan Beban Kerja tidak memiliki pengaruh secara tidak langsung terhadap Kinerja Pegawai melalui Kepuasan Kerja dan memberikan kesimpulan bahwa hipotesis ketujuh ditolak". Hasil penelitian ini menujukkan bahwa ketika terdapat perubahan pada beban kerja pegawai UKPBJ Sekertariat Daerah Mojokerto, memang akan mempengaruhi kinerja pegawainya, tetapi kepuasan kerja yang dirasakan pegawai juga sama (tidak meningkat/menurun). Sebab meskipun terdapat penambahan beban kerja, tidak akan berbeda dengan pekerjaan rutin masing-masing pegawai, hanya berbeda pada kuantitasnya saja bukan jenis pekerjaannya dan hal tersebut sangat jarang sekali terjadi, kecuali terdapat perubahan pimpinan yang membentuk kebijakan baru. Rutinitas pekerjaan (kinerja) yang dilakukan pun akan sama dari waktu ke waktu, sehingga tingkat kepuasan kerja yang dirasakan pun akan sama. Berdasarkan jawaban responden secara nyata telah membentuk hasil akhir bahwa tidak ada kaitan antara beban kerja pegawai ASN dengan kepuasan kerjanya dan pada akhirnya juga tidak akan berdampak pada kinerjanya.

\section{PENUTUP}

\section{Kesimpulan}

Penelitian yang telah dilakukan membentuk beberapa kesimpulan:

1. Analisa tentang pengaruh secara langsung kompensasi terhadap kepuasan kerja pegawai, maka diperoleh hasil bahwa kompensasi tidak memiliki pengaruh secara langsung terhadap kepuasan kerja pegawai di UKPBJ Sekertariat Daerah Mojokerto.

2. Analisa tentang pengaruh secara langsung beban kerja terhadap kepuasan kerja pegawai, maka diperoleh hasil bahwa beban kerja tidak memiliki pengaruh secara langsung terhadap kepuasan kerja pegawai di UKPBJ Sekertariat Daerah Mojokerto.

3. Analisa tentang pengaruh secara langsung kompensasi terhadap kinerja pegawai, maka diperoleh hasil bahwa kompensasi tidak memiliki pengaruh secara langsung terhadap kinerja pegawai di UKPBJ Sekertariat Daerah Mojokerto.

4. Analisa tentang pengaruh secara langsung beban kerja terhadap kinerja pegawai, maka diperoleh hasil bahwa beban kerja memiliki pengaruh secara langsung terhadap kinerja pegawai di UKPBJ Sekertariat Daerah Mojokerto.

5. Analisa tentang pengaruh secara langsung kepuasan kerja terhadap kinerja pegawai, maka diperoleh hasil bahwa kepuasan kerja tidak memiliki pengaruh secara langsung terhadap kinerja pegawai di UKPBJ Sekertariat Daerah Mojokerto.

6. Analisa tentang pengaruh secara tidak langsung kompensasi terhadap kinerja melalui kepuasan kerja pegawai, maka diperoleh hasil bahwa kompensasi tidak memiliki pengaruh secara tidak langsung terhadap kinerja pegawai melalui kepuasan kerja di UKPBJ Sekertariat Daerah Mojokerto.

7. Analisa tentang pengaruh secara tidak langsung beban kerja terhadap kinerja melalui kepuasan kerja pegawai, maka diperoleh hasil bahwa beban kerja tidak memiliki pengaruh secara tidak langsung terhadap kinerja pegawai melalui kepuasan kerja di UKPBJ Sekertariat Daerah Mojokerto.

\section{Keterbatasan dan rekomendasi untuk penelitian selanjutnya}

Penelitian ini memiliki jawaban hasil responden yang sesuai dengan kenyataan, tetapi hanya terbatas pada "pegawai yang berstatus Aparatur Sipil Negara (ASN)" sebanyak 44 orang, bukan seluruh pegawai di UKPBJ Sekertariat Daerah Mojokerto, sehingga jawaban yang diperoleh kurang beragam.

Saran dalam penelitian ini setelah dilakukan pengujian pada ketujuh hipotesis dan penarikan kesimpulan, yakni:

1. Hasil dalam penelitian ini dapat dijadikan referensi landasaran pemikiran bagi penelitian selanjutnya yang berkaitan dengan kompensasi, beban kerja, kinerja karyawan, dan kepuasan kerja dengan menambah jumlah responden pada penelitian.

2. Hasil penelitian ini selanjutnya dapat dijadikan 
gambaran karyawan UKPBJ Sekertariat Daerah Mojokerto tentang realita kompensasi, beban kerja, kinerja, dan kepuasan kerja pegawainya, sehingga diharapkan dapat terjadi perubahan pada kepuasan kerja dan kinerja pegawainya melalui pemberian kompensasi dan beban kerja, sebab hasil penelitian ini bertolak belakang dengan pada penelitian milik Pontoh (2014) yaitu kompensasi yang diberikan berpengaruh signifikan terhadap kepuasan kerja dan kinerja pegawai, sedangkan beban kerja yang diberikan berpengaruh signifikan terhadap kepuasan kerja tetapi tidak berpengaruh signifikan terhadap kinerja pegawai di Badan Perencanaan Pembangunan Daerah Propinsi Sulawesi Tengah.

3. Pada kesimpulan penelitian hanya ada satu hipotesis yang diterima, yakni beban kerja memiliki pengaruh secara langsung terhadap kinerja pegawai di UKPBJ Sekertariat Daerah Kota Mojokerto. Sehingga pada penelitian selanjutnya disarankan untuk menggunakan variabel Stress Kerja sebagai variabel eksogen atau variabel bebasnya

\section{REFERENCES}

Asbari, M., Santoso, P., \& Purwanto, A., (2019). Pengaruh Kepemimpinan Dan Budaya Organisasi Terhadap Perilaku Kerja Inovatif Pada Industri 4.0. Jurnal Ilmiah Manajemen Universitas Putera Batam.

Ghozali, I., (2017). Pengaruh Motivasi Kerja, Kepuasan Kerja dan Kemampuan Kerja terhadap Kinerja Pegawai pada Kantor Kementerian Agama Kabupaten Banjar. Jurnal Ilmiah Ekonomi Bisnis, 3(1).

Habe, H., (2012). Hubungan Kepuasan Kerja dengan Komitmen Karyawan pada Toko Buku Fajar Agung di Bandar Lampung. Jurnal Manajemen dan Keuangan, 10(2).

Halimah, S. N., (2017). Analisis Pengaruh Kualitas Layanan dan Kepuasan terhadap Loyalitas Pasien di Medical Center ITS dengan Metode Structural Equation Modeling - Partial Least Square (SEM). (Skripsi). Institut Teknologi Sepuluh Nopember Surabaya. Restricted from https://core.ac.uk/
Handayani, R. \& Soliha, V., (2020). Pengaruh Disiplin Kerja dan Suasana Kerja terhadap Kinerja Karyawan pada PT. Gunung Agung Tangerang Selatan. JENIUS, 3(2).

Haryono. (2004). Manajemen Sumber Daya Lanjutan. Jakarta: PT. Gramedia.

Katidjan, P.S., Pawirosumarto, S. \& Isnaryadi, A., (2017). Pengaruh Kompensasi, Pengembangan Karir, dan Komunikasi terhadap Kinerja Karyawan. Jurnal Ilmiah Manajemen, 7(3), 429-446.

Paramitadewi, K.F., (2017). Pengaruh Beban Kerja dan Kompensasi terhadap Kinerja Pegawai Sekretariat Pemerintah Daerah Kabupaten Tabanan. E-Jurnal Manajemen, 6(6), 3370-3397.

Pontoh, F. M. (2014). Pengaruh Kompensasi Dan Beban Kerja Terhadap Kepuasan Kerja Dan Dampaknya Pada Kinerja Pegawai Pada Badan Perencanaan Pembangunan Daerah Propinsi Sulawesi Tengah. (Tesis) Universitas Tadulako Palu. Restricted from http://jurnal.untad.ac.id/

Prayatna, N.U. \& Jawas, A., (2012). Faktor-faktor yang Dipertimbangkan Konsumen dalam Keputusan Pembelian Laptop merek Acer di Kota Denpasar. E-Jurnal Manajemen, 2(2).

Priansa, D. J. (2014). Perencanaan dan Pengembangan Sumber Daya Manusia. Bandung: Alfabeta.

Putra, D. P. (2017). Pengaruh Kepuasan Kerja, Motivasi Kerja dan Kepemimpinan terhadap Organizational Citizenship Behavior dan Kinerja Karyawan PT. MSH Niaga Telecom Surabaya. (Tesis), Institut Teknologi Sepuluh Nopember Surabaya. Restricted from https://core.ac.uk/

Sholihin, M. \& Ratmono, D., (2013). Analisis SEM-PLS dengan WarpPLS 3.0. Yogyakarta: Andi

Tjio, M.O. \& Angela, M., (2015). Analisis Pengaruh Lingkungan Kerja terhadap Kinerja Karyawan melalui Kepuasan Kerja Hotel X Surabaya. Jurnal Indonesia. Manajemen Perhotelan, Fakultas Ekonomi, Universitas Kristen Petra.

Wilson, B. (2012). Manajemen Sumber Daya Manusia. Jakarta: Erlangga. 